\title{
Analysis of Traditional Food Promotion in South Sulawesi
}

\author{
Sri Sulartiningrum ${ }^{1}$, Mohammad Syaltut Abduh ${ }^{2}$, and Wisnu Saputra ${ }^{3}$ \\ ${ }^{1,2,3}$ Sekolah Tinggi Pariwisata Trisakti, Jakarta, Indonesia \\ Email: ${ }^{1}$ msabduh@ stptrisakti.ac.id
}

\begin{abstract}
This study aimed to introduce some traditional foods of South Sulawesi, and to find out how far the public know them and want to know what promotion activities that are appropriate and efficient in introducing these foods to the society. The research method used descriptive method, closed question answer type, and data was collected by doing field research and library research, and spreading the questionnaires of 100 randomly selected respondents. The data were consisted of regional food. The analysis found that only three types of food is known among the five types of food introduced, and the promotion to introduce the food is still less. In addition to the five promotional activities asked only four promotional activities that all respondents answered yes. Those are demonstration, packaging, and labeling; this means that promotional activities turned out precise and efficient.
\end{abstract}

Keywords-Promotion, Food, and South Sulawesi.

\section{INTRODUCTION}

Indonesia has many typical foods that come from the region. One of them is from South Sulawesi which is famous as Coto Makassar. This food is one of Makassar's "trade mark" culinary. This food is soup with basic ingredients consisting of intestines, liver, brain, and beef, cooked with lemongrass spice, galangal, coriander, cumin, onion, garlic, mashed salt, bay leaves, lime, and nuts. In general Coto Makassar served with ketupat. There is also other food that is quite famous Konro Soup. The basic ingredients are cow ribs or buffalo, cooked / burned with coriander seeds, cumin, lemongrass, kaloa, onion, garlic, and salt. Konro Soup is generally served with steamed rice and chili sauce.

For South Sulawesi people, food is very close to their daily life, because foods such as Coto Makassar and Konro Sop is a food that is always provided in banquet. But not only that, there are many more South Sulawesi specialties that are not yet known by the wider community, such as Budu Budu, Langga Roko, Pallu mara, Nanre Benteng, Bale Tunu Kodenggareng, Maluku Paku Tumisi, Banana Epe, Paria Kambu, Welie Curry, and many others.

From the above explanation and because there are many traditional foods in South Sulawesi that have not been known by the wider community, and there is still very rare the recipes of southern Sulawesi in bookstores. Taking note of the problem above, it's interested in observing: first, how is the traditional food of South Sulawesi in known by the society out of South Sulawesi; and second, what is the appropriate promotion for the traditional food of South Sulawesi. So, the purpose of this study are: introducing the traditional food of South Sulawesi to the wider community; finding out how far the public know the traditional food of South Sulawesi; understanding how to introduce traditional food of South Sulawesi to the public; and finding out the appropriate promotion activities to introduce the traditional food of South Sulawesi.

\section{LITERATURE REVIEW}

\section{A. Promotion}

Promotion is one of the variables in the marketing mix that is very important to be implemented by companies in marketing service products (Lupiyoadi, 2001). Promotional activities is not only communication between companies and consumers, but also as a tool to influent consumer activities to purchase/ use services in accordance with the wishes and needs. In addition, the promotion also aims to promote new products.

According to Rathmell (2008), "Promotion is the effort to inform and persuade potential customers in order to accomplish the sale of the product, services, or ideas". It means that "Promotion is an attempt to inform and influence potential customers in offering the price of an item, service, or ideas". 
Another notion argued by Mc Namara (2008) that states the promotion as keeping the product in the minds of the customer and helps stimulate demand for the product. Promotion involves ongoing advertising and publicity (mention in the press). The ongoing activities of advertising, sales and public relations are often considered as aspects of promotions. It means that promotion is to instill in the minds of customers and influent customers about good. Promotional activities commonly used are advertences and publicity. Activities of advertisement, sales and public relations are aspects of promotion.

According to Marcoux (2008), promotion is first and foremost a communications tool, an instrument for transmitting the official corporate message and image to the four markets of the cultural enterprise". a. Promotion Instrument. According to Philip Kotler and Gary Armstrong promotional activities is the activities that are conducted by a company or institution includes:

1. Advertising, it is a form of presentation and promotion of ideas, goods or services financed by a particular sponsor of a non-personal nature. Media frequently uses in this advertisement are radio, television, newspaper magazines and billboards.

2. Personal selling, it is a verbal presentation in a conversation with someone or more prospective buyers with the aim to be realized sales.

3. Sales promotion, it is any marketing activity other than personal selling, advertisement and publicity, which stimulates consumer purchases and the effectiveness of agents such as exhibitions, performances, demonstrations and any sales efforts that are not regularly or continuously performed.

4. Publicity, it is an attempt to stimulate the demand of a product in a non-personal manner by making, either in the form of commercial news about the product in printed media or not, or the results of interviews broadcast in the media.

One of the marketing activities is promotion. Promotion is a very appropriate means to introduce a product to the public. With the promotion is expected the public will see and pay attention to the product presented and interested to try the product presented.

\section{B. Traditional Food of South Sulawesi}

South Sulawesi consists of various tribes such as Tana Toraja, Bugis Tribe and Makassar Tribe. Each tribe has traditional food. This can be seen from the types of vegetable dishes, staple foods, side dishes, and traditional cakes. The food is as follows:

1. Sop Kaluku Lolo (Young Coconut Soup)

The basic ingredients are young coconut meat, with additional ingredients such as carrots, long beans, corn, and squid.

2. Nanre Betteng (Rice Millet)

As a staple food in some areas in South Sulawesi is Nanre Betteng (Jawawut). "Betteng" is a substitute for rice or can be mixed a little rice and can also be used as a traditional pastry (dessert). "Betteng" is produced by Enrekang and Selayar districts. This Betteng Nanre is included in the main course.

3. Bale Tunu Kodengareng (Ikan Bakar Kodengareng)

Kodengareng is one of the islands in South Sulawesi which is famous for grilled fish and Raca - Raca

Pao or Acar Mangga. grilled fish are usually grilled by using charcoal or coconut shell or coconut belt, so it has a more delicious flavor and smells burnt.

In general, fish that is often used is snapper fish, which before it's grilled, the fish is skinned and filleted, the food process is a bit difficult and needed special skill, because this grilled fish is very different when compared with grilled fish that we often found.

4. Tumisi paku Malino (Vegetable Stir-fry)

Vegetable nails (ferns) are vegetables that grow a lot of tourist areas are cool air. In processing, the vegetables is combined by dangke (cheese Enrekang) baked with fried shrimp, so it has a high nutrition. Vegetable fern is a companion dish that is combined by any main course. Vegetable nails are the daily food of people in Malino area.

5. Es Pisang Hijau (Green Banana Ice)

This dish is one of the favorite desserts of South Sulawesi residents. It can be found in almost every place in South Sulawesi. Although the basic ingredients are bananas, but the processing is different from Pallubutung Ice, because the food is made from plantain, wrapped in wheat flour that has been 
given coconut milk and pandan leaves as a colorant and fragrance is green, served with ice-filled sauce shrink and syrup.

Based on the literature above the framework of the study is described in figure 1 .

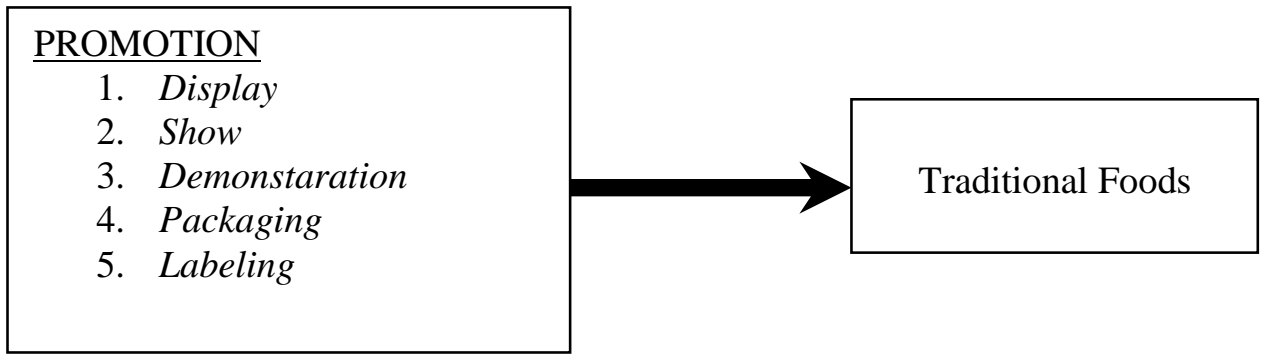

( Source: Ward, Susan, 2008 )

Fig. 1. Research thinking framework

\section{METHODS}

The research method used is descriptive research method. This method is used to describe a situation or event. But this method not only provides an overview of the phenomena, but also makes predictions and gets the meaning and implications of a problem to be solved.

TABLE I. VARIABLE, INDICATOR AND NO QUESTION

\begin{tabular}{lll}
\hline Variabel & \multicolumn{1}{c}{ Indicator } & \multicolumn{1}{c}{ Number of questions } \\
\hline \multirow{3}{*}{ Promosi } & 1. Display & 1. No $1-2$ \\
& 2. Show & 2. No $3-4$ \\
& 3. Demonstration & 3. No 5-6 \\
& 4. Packaging & 4. No 7-8 \\
& 5. Labeling & 5. No 8-10 \\
& 6. Traditional foods & 6. No 11-12 \\
\hline
\end{tabular}

The questionnaire is "closed questions". The answers are provided first, and the respondents just check the answers based on the instructions, and there are some questions that the answers provided are "yes" and "no".

Sample is part of the population or part of the characteristics possessed by the population. The sample used in this research is 100 people in South Jakarta. 


\section{RESULT AND DISCUSSION}

TABLE II. GENDER

\begin{tabular}{lccc}
\hline Gender & Male & Female & Total \\
\hline The number of respondents & 46 & 54 & 100 \\
$\%$ & 46 & 46 & 100 \\
\hline
\end{tabular}

Source: Processed Data

Based on the data above table can be explained that the gender of the respondents consist of male are 17 people $(56.7 \%)$, and female are 13 people $(43.3 \%)$ of the total number respondents 30 people. This means that the number between female and male is almost equal.

TABLE III. AGE

\begin{tabular}{lcccccc}
\hline \multicolumn{1}{c}{ Age (years) } & $<20$ & $21-29$ & $30-39$ & $40-49$ & $>50$ & Total \\
\hline $\begin{array}{l}\text { The number of } \\
\text { respondents }\end{array}$ & 13 & 34 & 25 & 20 & 8 & 100 \\
$\%$ & 13 & 34 & 25 & 20 & 8 & 100 \\
\hline
\end{tabular}

Source: Processed Data

Based on the above table it can be explained that the percentage of respondent's age, <20 years old are 13 people (13\%), aged between 21-29 years are 34 people (34\%), aged between $30-39$ years are 25 people (25\%), aged between $40-49$ years are 20 people (20\%), and aged $>50$ years are 8 people $(8 \%)$ of the 100 respondents. If we consider from the age of respondents it can be concluded that the average respondent is at productive age, and in general they're interested in try something new.

TABLE IV. EDUCATION

\begin{tabular}{lcccccc}
\hline Education & $\begin{array}{c}\text { Senior } \\
\text { High } \\
\text { School }\end{array}$ & $\begin{array}{c}\text { Diploma } \\
1\end{array}$ & $\begin{array}{c}\text { Diploma } \\
3\end{array}$ & $\begin{array}{c}\text { Diploma } \\
\text { 4/Undergraduate }\end{array}$ & $\begin{array}{c}\text { Post- } \\
\text { graduate }\end{array}$ & Total \\
\hline $\begin{array}{l}\text { Number of } \\
\text { respondents }\end{array}$ & 12 & 4 & 16 & 68 & 17 & 100 \\
\hline
\end{tabular}

Source: Processed Data

From the table above, it shows that the respondents of high school are 12 people, Diploma 1 are 4 people, Diploma 3 are 16 people, Diploma 4 / undergraduate are 68 people, and Post graduate are 17 people, of the total number of respondents as many as 100 people. This means that respondents have education strata ranging from high school to D4 / S1, therefore the information submitted will be faster they receive, then the information to be delivered is packaged well to attract attention.

\section{TABLE V. DISPLAY}

\begin{tabular}{cccc}
\hline Question & Yes & No & Total \\
\hline $\begin{array}{l}\text { Is promotional activity by placing the food in the } \\
\text { showcase effective to introduce the food to the society? }\end{array}$ & 28 & 72 & 100 \\
\hline
\end{tabular}

\section{Source: Processed data}

From table 2 shows that the respondents who answered "Yes" are 28 people or 28/100 X 100\% = $28 \%$, while respondents who answered "No" are 72 people or $72 / 100 \times 100 \%=72 \%$. Based on the results, it means that it is not enough to promote food by displaying, because the information about the product can't be communicated clearly. 
TABLE VI. DISPLAY

\begin{tabular}{cccc}
\hline Question & Yes & No & Total \\
\hline Is displaying food able to attract the attention of people? & 65 & 35 & 100 \\
\hline
\end{tabular}

Source: Processed data

From table 3 above shows that respondents who answered "Yes" are 65 people or $65 / 100 \times 100 \%=$ $65 \%$, while respondents who answered "No" are 35 people or $35 / 100 \times 100 \%=35 \%$. Based on the answers of respondents above it means that food that is displayed is able to attract the attention of people who see it, live how the food products are packed to be more interesting again, so people who see it interested to try the food products on display.

TABLE VII. SHOW

\begin{tabular}{lccc}
\hline Question & Yes & No & Total \\
\hline Is it important to show food information? & 100 & - & 100 \\
\hline
\end{tabular}

Source: Processed data

From the table above shows that all respondents answered "Yes" are 100 people or 100/100 X 100\%= $100 \%$, while respondents who answered "No" is none or $0 / 100 \times 100 \%=0 \%$. Based on the answers, they believe that showing food information will be easier to recognize the food, so people will be interested to taste the food to be promoted.

TABLE VIII. SHOW

\begin{tabular}{cccc}
\hline Question & Yes & No & Total \\
\hline Is food information is able to pull the people to taste? & 100 & - & 100 \\
\hline
\end{tabular}

Source: Processed data

From the table above shows that all respondents answered "Yes" are 100 people or 100/100 X 100\%= $100 \%$, while respondents who answered "No" is none or $0 / 100 \times 100 \%=0 \%$. Based on the answers from the respondents above, it means that information about the food is able to pull the people to taste.

TABLE IX. DEMONTRATION

\begin{tabular}{cccc}
\hline Question & Yes & No & Total \\
\hline Is it important to show food processing? & 100 & - & 100 \\
\hline
\end{tabular}

Source: Processed data

From the table above shows that respondents who answered "Yes" are 100 people or 100/100 X 100\% $=100 \%$, while respondents who answered "No" is none or $0 / 100 \mathrm{X} 100 \%=0 \%$. Based on the answers of respondents above, that all respondents consider it important if they see the process of making of food, because by looking directly at the process of making it people will know the quality of the processed food.

\section{TABLE X. DEMONTRATION}

\begin{tabular}{lccc}
\hline \multicolumn{1}{c}{ Question } & Yes & No & Total \\
\hline $\begin{array}{l}\text { Is demontration of cooking the food able to attract the } \\
\text { attention of people? }\end{array}$ & 100 & - & 100 \\
\hline Source: Processed data & & & \\
\hline
\end{tabular}

Source: Processed data 
From the table above shows that respondents who answered "Yes" are 100 people or 100/100 X 100\% $=100 \%$, while respondents who answered "No" is none or $0 / 100 \mathrm{X} 100 \%=0 \%$. Based on the answers all respondents think that if they see directly the process of making of a food, then it can attract their attention. This is because if we look directly at the process of making a food then we will easily to know the ins and outs of the food, so we will feel safe to try the processed food.

\section{TABLE XI. LABELLING}

\begin{tabular}{cccc}
\hline Question & Yes & No & Total \\
\hline Is food exhibition able to introduce food to people? & 100 & - & 100 \\
\hline Source: Proces
\end{tabular}

Source: Processed data

From the table above shows that respondents who answered "Yes" are 100 people or 100/100 X 100\% $=100 \%$, while respondents who answered "No" is none or $0 / 100 \mathrm{X} 100 \%=0 \%$. Based on the respondent's answer above, this means that if you want to introduce a food product it is very appropriate to introduce at the exhibition or festival, because at that time many people who come to see the exhibition held, then it becomes an opportunity right to promote or introduce our products.

TABLE XII. LABELLING

\begin{tabular}{cccc}
\hline Question & Yes & No & Total \\
\hline Must food exhibition be held more often? & 100 & - & 100 \\
\hline
\end{tabular}

Source: Processed data

From the table above shows that respondents who answered "Yes" are 100 people or 100/100 X 100\% $=100 \%$, while respondents who answered "No" is none or $0 / 100 \mathrm{X} 100 \%=0 \%$. Based on the respondents' answers above, this means that exhibitions or festivals should be frequent to introduce a more food product, so that there will be many more foods that can be known by the people and that is very good because the original foods Indonesia can continue to be conserved, especially food originating from South Sulawesi.

TABLE XIII. PACKAGING

\begin{tabular}{lccc}
\hline \multicolumn{1}{c}{ Question } & Yes & No & Total \\
\hline Is packaging important ? & 100 & - & 100 \\
\hline Source: Processed data & &
\end{tabular}

Source: Processed data

From the table above shows that all respondents answered "Yes" are 100 people or 100/100 X 100\% = $100 \%$, while respondents who answered "No" is none or $0 / 100 \times 100 \%=0 \%$. From the table above all respondents answered that the way of serving of a food is important, because if presented well and interesting it will make people curious to taste the food.

\section{TABLE XIV. PACKAGING}

\begin{tabular}{llccc}
\hline Question & Yes & No & Total \\
\hline $\begin{array}{l}\text { Do you think that presentation can be the main } \\
\text { attraction of a particular type of food? }\end{array}$ & 100 & - & 100 \\
\hline
\end{tabular}

Source: Processed data

From the table above shows that all respondents answered "Yes" are 100 people or 100/100 X 100\%= $100 \%$, while respondents who answered "No" is none or $0 / 100 \times 100 \%=0 \%$. Based on the answers of respondents above, it means they believe that the way of serving of a type of food that can be an 
attraction, because if a food is presented with Very beautiful it will cause a good impression, so the food will always be remembered.

\section{TABLE XV. TRADITIONAL FOOD}

\begin{tabular}{lccc}
\hline Question & Yes & No & Total \\
\hline Do you know: & & & \\
1. Sop Kaluku Lolo & 11 & 89 & 100 \\
2. Nanre Betteng & - & 100 & 100 \\
3. Bale Tunu Kodengareng & - & 100 & 100 \\
4. Tumisi Paku Malino & 5 & 95 & 100 \\
5. Es Pisang Hijau & 36 & 64 & 100 \\
\hline
\end{tabular}

Source: Processed data

From the table above shows that of the 5 types of food introduced, the most widely known green banana ice are 36 people or $36 / 100 \times 100 \%=36 \%$, and respondents who answered did not know the food are 64 people or $64 / 100 \times 100 \%=64 \%$. From the above explanation, it turns out the food known by the respondents is where the food is almost there in every place to eat that provides dishes South Sulawesi. This happens because:

1. The basic ingredients of the food are easy to obtain i.e. bananas.

2. Cooking methods or how to make it relatively easier.

3. Prices are relatively cheap and vary from $\mathrm{Rp} 5000$ - Rp 6000, depending on how the presentation and where the food is sold.

And who knows Sop Kaluku Lolo are 11 people or $11 / 100$ X $100 \%=11 \%$, and who do not recognize are 89 people or $89 / 100$ X $100 \%=89 \%$, and who knows Tumisi Paku Malino are 5 people or $5 / 100 \mathrm{X}$ $100 \%=5 \%$, and who do not recognize are 95 people or $95 / 100 \times 100=95 \%$.

Whereas from 5 types of food introduced, there are 2 types of food that is not known by the respondents, namely Nanre Betteng and Bale Tunu Kodengareng.

From the above explanation it can be concluded that:

1. distribution of food for sale in places to eat that provides typical dishes of South Sulawesi in Jakarta must be improved.

2. places to eat that provides typical dishes of South Sulawesi in Jakarta must be increased.

3. promotions undertaken to introduce these foods must be improved.

\section{TABLE XVI. COOKING METHOD}

\begin{tabular}{llcc}
\hline \multicolumn{1}{c}{ Question } & Yes & No & Total \\
\hline Is cooking method influent the food quality? & 100 & - & 100 \\
\hline Source: Processed data & & &
\end{tabular}

From the table above shows that all respondents answered "Yes" are 100 people or 100/100 X 100\%= $100 \%$, while respondents who answered "No" is none or $0 / 100 \times 100 \%=0 \%$. Based on the answers from the respondents above, they believe that with the correct method of cooking, the quality of the processed food will be better, so it will make the food safe for consumption.

\section{CONCLUSION}

The typical food of South Sulawesi is still less known by the wider community. This can be seen from the five types of food introduced, there are only three types of food known by the respondents, it also does not reach the percentage of $50 \%$. This means that the food of South Sulawesi is indeed to be introduced. 
It turns out from the five promotional activities that there are only four appropriate promotional activities and efficient to introduce food originating from South Sulawesi, that is with promotional activities such as show, demonstration, packaging, and labeling.

\section{REFERENCES}

Alma, Buchari.(2000). Manajemen Pemasaran dan Pemasaran Jasa. Bandung : Alfabeta.

Lupiyoadi.(2001). Rambat. Manajemen Pemasaran Jasa. Jakarta : PT Salemba Emban Patria.

McNamara, Carter. (2008). One Definition of Promotion. http://www.managementhelp. org/ad_promot/definition.htm, download 13 september 2008.

Rathmell, John M. (2008). Managing the Marketing Function. John Wiley \& Sons, Inc. http://www.engin.brown.edu/courses/en9/spring/ download 12 septermer 2008.

Ward, Susan. (2008). Promotion Definition. http://sbinfocanada.about.com/cs/marketing/ g/promotion.htm, download 13 september 2008.

(2008). Promotional Mix Produk. http://organisasi.org/definisi-pengertian-promosi-fungsitujuan-bauran-promosi-promotional-mix-produk, download 12 septermer 2008. 